\title{
NEW SPECIES OF NORTH AMERICAN DOLICHOPODIDÆ (DIPTERA)
}

\author{
By M. C. Van Duzee. \\ Buffalo, N. Y.
}

Mesorhaga pallidicornis sp. nov.

Male: Length $3 \mathrm{~mm}$. Face metallic green with abundant white pollen. Front blue-green with white pollen above the antennæ and along the orbits. Occular bristles black, bristles at upper corners of the eyes yellow. Proboscis yellow; palpi black, yellow on apical half. Antennæ with the two basal joints blackish; third joint reddish yellow, black on upper basal corner, nearly round in outline; bristles on second joint white; the basal arista brown. Orbital cilia white, becoming short above, scarcely reaching the upper orbit.

Mesonotum, base of scutellum and metanotum shining blue; remainder of scutellum, pleuræ and abdomen metallic green, pleuræ dulled with white pollen. All bristles and hairs of the thorax and abdomen yellowish. Hypopygium shining black; its appendages testæcous, somewhat oval in outline, more than half as long as the hypopygium, their hairs small and yellow.

Fore coxæ, all femora and tibiæ pale yellow; midd e and hind coxæ black; hairs and bristles on all femora, coxæ, and tibiæ yellow, there are several blackish bristles on posterior tibi $æ$, but these appear yellow in certain lights, the hairs on fore coxæ and lower surface of fore and middle femora are long and almost white. Tarsi longer than their tibiæ, yellow, becoming brown towards their tips. Joints of fore tarsi are as 40-11-9-7-6; those of middle ones as 54-17-13-7-7; joints of posterior tarsi as 39-30-18-9-6. Knobs of halteres yellow. Calypters yellow with a narrow brown border and long yellow cilia.

Wings a little grayish; veins brown; venation as usual in the genus.

Described from one male taken at Sandusky, Ohio, July 9, 1904, by E. P. Van Duzee. Type in the author's collection 
This is the only species known as far as I can find that has the antennæ partly yellow; in all others described from North and South America and Asia (there are none in Eur pe the antennæ are wholly black.

\section{Neurogonia minima sp. nov.}

Male: Length $1.5 \mathrm{~mm}$. Face wide, narrowed below, blackish. Front and occiput black with white pollen. Antennæ brown, third joint small, somewhat conical in outline, abruptly narrowed where the arista is inserted extended into an outuse point; arista pubescent, inserted near the middle of the upper edge of third joint. Orbital cilia minute, pale; bristles of the head reddish.

Thorax reddish brown, dorsum dull brown; depressed space before the scutellum large, dark brown with gray pollen; I cannot see any acrostichal bristles; dorsocentrals large, black when viewed from above, still against a dark background they appear more or less yellow. Abdomen blackish, hypopygium more reddish brown, large, somewhat pedunculate, oval, but a little narrowed towards the tip, where there are minute lamellæ and a fringe of long hairs.

Coxæ, femora, tibiæ and tarsi yellow, middle and hind tarsi a little infuscated on outer surface; fore coxæ with white hairs, legs without long hairs. Joints oc fore tarsi are as 17-8-6-5-4; of middle ones as 22-11-7-5-5; those of posterior pair as 12-14-96-5. Calypters, their cilia and the halteres yellow.

Wings grayish; second, third and fourth veins nearly straight and a little divergent from opposite the middle of the first vein; cross-vein near the middle of the wing; first vein reaching about half the distance to the cross-vein.

Described from one male taken at Ithaca, New York, August 28, 1894. Type in the Cornell University Collection.

This differs from nigricornis Van Duzee in having the antennæ more pointed at tip, the thorax dull, not at all shining, the hypopygium less bulky, coxæ and legs darker, especially the middle and hind coxæ, the bristles of the head more reddish, and in being smaller in size. 


\section{Medeterus emarginatus Van Duzee.}

Psyche, xxv, p. 439, 1914.

Male: like the female in size and color. The hypopygium is large, black, with apical portion shining, the hairs on basal part and its apical appendages yellowish. Joints of posterior tarsi as 33-35-32-14-9. Last section of fifth vein 26 fiftieths of a millimeter long. There are three black bristles above each fore coxa, the anterior coxæ have a row of long hairs on outer edge of the front surface, these hairs are also found in the females taken with this male.

One male and three females were taken at Peru, Clinton County, New York. The male and two females are in the Cornell University collection.

\section{Medeterus minimus sp. nov.}

Male: Length $1.6 \mathrm{~mm}$. Face moderately wide, black, lower part without pollen, upper portion and the front opaque with brown pollen. Palpi and proboscis brown. Antennæ black. Lower part of occiput with a few pale hairs.

Thorax opaque with brown pollen and with a darker median stripe, which nearly reaches the scutellum, the latter with one pair of marginal bristles. Abdomen blackish with green reflections, dulled with brown pollen, its hairs pale. Hypopygium thick and obtuse at apex, shining black.

Coxæ black, extreme tip yellowish. Femora more or less blackened. Tibiæ and tarsi yellow. The joints of hind tarsi are as 15-15-9-8-6. Calypters yellowish with white cilia. Knobs of halteres whitish.

Wings grayish, venation typical of the genus, veins yellowish; last section of fifth vein 17 , of cross-vein 8 fiftieths of a millimeter in length.

Described from one male, taken at Felton, St. Cruz Mts., California, May 20, 1907, by J. C. Bradley.

Type in the Cornell University collection. 
Hydrophorus criddlei sp. nov.

Male: Length 3-3.2 mm.; of wing 4.2-4.7 mm. Face rather wide, silvery white, the green ground color shows through a little on upper third, lower portion a little longer than wide, evenly rounded on its lower edge. Palpi black with white pollen, which is not silvery, covered with delicate pale hairs and with several stouter, black, very short ones. Antennæ black, third joint rounded at tip. Front opaque brown. One pair of postverticals; the black orbital cilia extend down to the middle of the eye. Beard rather bright yellow, quite long, there are several black bristles under the neck.

Thorax green, dorsum nearly opaque with brownish pollen; pleuræ with thin brown pollen; propleura with one long black bristle and a few pale hairs above fore coxa; acrostichal bristles small, reaching nearly to the front of the thorax; dorsocentrals moderately large; scutellum with four marginal bristles. Abdomen green with white pollen on the sides, its hairs mostly black, only a few very small white hairs on the sides and at tip. Hypopygium mostly concealed, it has a small black appendage projecting below and the posterior edge of fourth abdominal segment also extends downward a little in the center of its ventral surface.

Coxæ black; anterior pair with white pollen and long, but not very abundant, yellow hair on the front surface, these hairs become a little shorter towards the apex, I cannot see any black spines, even at tip. Femora and tibiæ green; fore femora thickened at base, tapering to the tip, they have a row of five black spines on lower surface of basal third, three of which are as long as the thickness of the tibia, the two nearest the base shorter, there are also many long pale hairs on the lower surface, these are longer than the spines and extend from the base almost to the tip, where they are shorter and further apart. Fore tibiæ with a row of spines extending their whole length. Middle femora towards the tip and middle tibiæ with two or three very slender, but rather long bristles on the anterior surface. Tarsi black, plain. Joints of fore tarsi are as 30-16-13-9-11; those of middle pair as 41-20-15-10-12; joints of hind tarsi as 38-26-18-12- 
12. Calypters yellow with yellowish cilia, halteres dark yellow, sometimes yellowish brown.

Wings dark grayish; cross-vein a little clouded; third vein only a little bent back towards the tip, nearly parallel with fourth; last section of fifth vein 14, cross-vein 19 fiftieths of a millimeter.

Female: Length 2.5-3.2 mm; of wing 3.5-4 mm. Face with grayish pollen, its lower portion about as long as wide, evenly rounded on oral edge. Fore coxæ with two very small black spines at base ( I cannot see these in the male). Femora with about eight irregularly placed short spines on lower surface of basal half and several longer ones, they also have the same long pale hairs as are found in the male, but they are a little shorter. The wings are about the same as in the male, except that in two of the females there is no cloud on the cross-vein and the wings are more clear.

Described from two males and three females, all taken at Awene, Manitoba, October 7, 1924, by N. Criddle, after whom I take pleasure in naming this interesting species.

\section{Hydrophorus fulvidorsum sp. nov.}

Male: Length $4.2 \mathrm{~mm}$. Face wide, only slightly narrowed above, brownish gray, wholly opaque, the lower portion not as long as wide, a very little pointed in the center. Front opaque brown. Antennæ black (only the first joint present on the type). Occiput green with brown pollen. Cheeks narrow. A row of bristles extend each way from the postverticals, joining the orbitals rather far down; the black orbital cilia extend down to the middle of the eye; beard white, not very abundant, there are a few black bristles under the neck.

Thorax green, covered with thick brown pollen, the poster or part and the scutellum more shining; humeri with gray pollen; pleuræ nearly opaque with brown pollen, which appears more gray when viewed from below; scutellum with one pair of marginal bristles; I can see no acrostichal bristles in the anterior half of the dorsum (in the type the posterior half is injured by the pin); propleuræ with a cluster of long pale hairs above each 
fore coxa, but without a black bristle. Abdomen blue-green with abundant brown pollen on the sides; the hairs on its dorsum short, black, on the sides the hairs are longer and white. Hypopygium mostly concealed; its appendages black, they consist of a minute pair of lamellæ fringed with hairs and a central organ extending from the base of the hypopygium, all these projecting backward.

Coxæ with brownish gray pollen; anterior pair with rather long, delicate, white hairs, without black bristles; femora and tibiæ green. Fore femora considerably thickened at base, tapering to their tips; they have two rows of short spines extending nearly their entire length, those in the anterior row are smaller and more scattering than those in the posterior row. Fore tibiæ with a small angle below at the tip projecting towards the femora; they have two rows of nearly erect spines on inner surface; those in anterior row more slender and numerous, extending the entire length of the tibia to the tip of the apical angle; those in posterior row a little stouter, about eight in number and not reaching base or tip. Tarsi blackish; joints of fore tarsi as 42-23-17-12-12; those of middle tarsi as 54-28-20-1513; joints of posterior ones as 60-37-26-20-15; fifth joint of middle tarsus a very little widened. Calypters brown with white cilia. Knobs of halteres pale yellow.

Wings tinged with brownish gray, with a cloud on the cross-vein; third vein bent backward at tip so as to approach fourth at tip, where they are one third as far apart as at the crossvein.

Described from one male taken at Chin, Alberta, May 3, 1923, by H. L. Seamans. Type in the Canadian National Museum.

This is very much like intentus Aldrich. They have the same wing characters, about the same formation of the hypopygium and the form of the fore femora are about the same. This form has no black bristles above the fore coxæ, the scucellum has only one pair of bristles, but the others may have been broken off, the first joint of the antennæ are shorter, and the spines on the fore femora seem much shorter; these variations would seem to be enough to separate the species, and I am ven- 
turing to publish it as a new species, still it may prove to be the same when we have a series of specimens from the type location.

\section{Dolichopus maculitarsis sp. nov.}

Female: Length $4-4.5 \mathrm{~mm}$. Face wide with white pollen. Front green with bronze reflections. Antennæ black, lower half of first and second joints yellow. Lower orbital cilia white, upper cilia black.

Thorax, scutellum and abdomen green with bright bronze reflections; hairs of the abdomen black.

All coxæ black, their hairs short and black. Fore femora black with their tips broadly yellow. Middle and hind femora yellow, black at base for a short distance, each with one preapical bristle. Fore and middle tibiæ blackish, more or less yellow at base, middle ones sometimes yellowish on upper surface to near the tip; posterior tibiæ and anterior and posterior tarsi wholly black; middle tarsi with basal portion of each joint dull whitish, contrasting with their black tips, fifth joint wholly black, each joint a little enlarged at tip. Joints of fore tarsi are as 38-18-13-10-13; of middle ones as 56-31-23-17-17; joints of posterior tarsi as 52-55-34-24-17. Each joint of middle tarsi with a few minute spines below and a bristle or spur at tip. Calypters and halters yellow, the former with dense, deep black cilia, which is of moderate length.

Wings grayish, a little yellow at root; bend in last section of fourth vein rather abrupt and near its middle; cross-vein 22 , last section of fifth vein 53 fiftieths of a millimeter; anal angle of wing prominent.

Described from two females. The holotype was taken at Baldur, Manitoba, June 23, 1924, by H. D. Bird, and is in the Canadian National Museum; the paratype was taken at the same place and time, by N. Criddle.

This is very much like the female of appendiculatus Van Duzee, Cole \& Aldrich. The middle tarsi of both are formed and colored alike. Both have the first two antennal joints largely yellow. They differ in the amount of yellow on the antennal joints, in the new form these joints have the upper half black, 
while in the older species they are only narrowly black on upper edge; all femora and tibiæ are wholly black in appendiculatus, while in this form the middle and hind femora are almost wholly yellow, the fore and middle tibiæ are more or less yellow at base, at least above, the joints of the tarsi are of somewhat different lengths in the two species, the measurements of the new form are given above; the joints of the middle tarsi of appendiculatus are as 47-27-27-15-15; and those of posterior ones are as 40-4829-17-13; the wings in the two forms are about alike.

\section{Hercostomus purpuratus sp. nov.}

Male: Length 3.5-4 mm. Face covered with white pollen, wide, concave almost to the lower edge, there not being any very distinct separation between the upper and lower parts; oral margin straight, a little projecting. Front shining blu with purple reflections. Antennæ black; first joint as long a second and third taken together, the latter two taken together nearly round in outline, the arista being inserted near the middle of their upper edge, its pubescence long. Palpi black with black hair. Orbital cilia wholly black.

Dorsum of thorax and the scutellum purple or violet, the edges more blue, the front slope and the pleuræ greenish; pollen on the dorsum brown, on the pleuræ white. Abdomen dark green with black hair. Hypopyigum black, its lamellæ large, nearly round in outline, sordid white with broad black border, which is jagged and bristly; inner appendages whitish, lamella-like, widened from the narrow base to apical margin, they have several minute hairs near the apex.

All coxæ black; anterior pair with small black hairs on the front surface and a row of bristles at tip. All femora and tibiæ yellow, upper edge of anterior femora brown, somet:mes they are almost wholly yellow; posterior tibiæ a very little brownish at tip on inner side; fore and middle tibiæ with strong bristles. Posterior femora on apical half and their tibiæ on basal half with long, delicate, brown hairs on lower posterior surface; these hairs are as long as the width of the femora; posterior tibiæ with a row of four large bristles on upper posterior edge of basal 
half, and a ow of five on upper anterior edge, these last inserted at nearly regular intervals for their whole length, they also have a glabrous line on upper edge. Fore and middle tarsi black from the tip of the first joint, hind tarsi wholly black. Joints of fore tarsi are as 38-18-15-10-10; of middle ones as 49-23-17-14-13 those of posterior pair as 42-45-29-18-15. Calypters and halteres yellow, the former with black cilia.

Wings tinged with blackish; costa with an enlargement which fills in the space between the first vein and the costa at the tip of the first vein for a considerable distance; third vein bent backward towards the tip, nearly parallel with fourth; last section of fifth vein 42 , of cross-vein 27 fiftieths of a millimeter in length; cross-vein at nearly right angles to fourth vein; anal angle prominent.

Female: Color of all parts as in the male, except that the posterior tibiæ are a little more brown at tip; antennæ as in the male; face a little wider and more convex on lower part; no cilia on the lower surface of posterior femora or tibiæ; hind tibiæ with three bristles in the row on upper posterior edge of basal half; wings without an enlargement of the costa. Otherwise about as in the male.

Described from four males and one female, all taken at Stockton, Manitoba, July 29, 1924, by N. Criddle. Holotype and allotype in the Canadian National Museum.

This is a very interesting species with a number of striking characters in the male; the female will be easily recognized by its dark wings; violet or blue front and thorax, dark upper edge of the anterior femora and the yellow hind tibiæ with their wholly black tarsi.

\section{Gymnopternus Loew.}

At present I am useing the generic name Gymnopternus Loew (Neue Beitr., V, 10, 1857) in the sense of a subgenus of Hercostomus Loew (Neue Beitr., V, 9, 1857), following Dr. Lundbeck in this (Dolichopodidæ of Denmark, 1912), however Dr. Theodore Becker unites the two genera under the name Hercostomus, not giving Gymnopternus even subgeneric value, 
but to me it seems best, for the present at least to follow Dr. Lundbeck and use the name Gymnopternus as a subgenus.

Most of our species are easily separated, especially in the male, the male hypopygial lamellæ of the Hercostomus being large and formed about as in the genus Dolichopus; while those of the forms coming under Gymnopternus are small and more or less crescent shaped; in almost all the species of Hercostomus, as thus separated, the last section of fourth vein is bent or it is convergent with third vein in both male and female; while in the subgenus Gymnopternus the third and fourth veins are almost parallel beyond the cross-vein.

As in most large genera, we have some species which are rather difficult to place if we have only the female; the exceptions that I know of among the North American species are, Hercostomus metatarsalis Thomson and $H$. vetius Melander, in which the bend in the last section of fourth vein is small, and Gymnopternus convergens Van Duzee, where these veins are decidedly convergent, but not as much so as in Hercostomus unicolor Loew.

Two species which I have described some time ago as Paraclius ornatus and flavicornis should be placed in the genus Hercostomus, as both have the third and fourth veins convergent beyond the cross-vein, as in Hercostomus unicolor Loew.

\section{Gymnopternus flavitarsis sp. nov.}

Male: Length $2.5 \mathrm{~mm}$. Face very narrow below, blackish. Palpi black. Front green with whitish pollen. Antennæ black; third joint small, scarcely as long as wide, somewhat rounded, scarcely pointed at tip; arista basal, as long as the face.

Thorax and abdomen green with white pollen; hairs on the abdomen black. Hypopygium black; its lamellæ dark yellow with a narrow black border, fringed with rather long black hairs; inner appendages yellow with a few black hairs at tip.

All coxæ black, the hairs on anterior pair black, short on basal half, longer and with some bristles mixed with them towards the tip. All femora black with yellow tips, without longer hairs below. All tibiæ wholly yellow. All tarsi yellow, only a little darker at tip. Posterior tibiæ and tarsi not at all 
thickened. Joints of fore tarsi as 23-10-8-6-7; of middle ones as 28-19-12-9-8; joints of hind tarsi as 20-24-17-11-9. Calypters and halteres yellow, the former with pale cilia.

Wings grayish; third and fourth veins parallel, but both slightly bent backward at tip; last section of fifth vein 20 , of cross-vein 15 fiftieths of a millimeter.

Described from one male taken at Gloversville, N. Y., by C. P. Alexander. Type in the Cornell University Collection.

\section{Gymnopternus maculiventris sp. nov.}

Male: Almost wholly yellow, with black hairs and bristles, nearly related to flavus Loew.

Length $3 \mathrm{~mm}$. Face yellow, narrow below. Front blackish on upper half, covered with white pollen. Occiput blackish with white pollen. Antennæ yellow; third joint slightly longer than wide, pointed at tip, its apical half brown; arista black, pubescent.

Thorax and abdomen yellow, they have a slight green reflection in spots when viewed in certain lights, their hair and bristles black; abdomen with poorly defined, black spots on third and fourth segments. Hypopygium black, its lamellæ small, yellow, fringed with stiff black hairs.

Coxæ, femora, tibiæ and tarsi pale yellow; posterior tarsi slightly infuscated from the tip of first joint, which has a small bristle at tip. Joints of fore tarsi are as 28-15-12-9-8; those of middle ones as 30-19-16-12-8; joints of posterior pair as 23-2415-15-8. Calypters, their short cilia and the halteres pale yellow.

Wings yellowish gray with yellow veins; third and fourth veins parallel; last section of fifth vein 26 , cross-vein 13 fiftieths of a millimeter; sixth vein short.

Described from one male, taken at Cold Spring Harbor, New York, August 9, 1920, by Mr. Davis. Type in the author's collection.

This differs from flavus Loew in having the third antennal joint short, the hairs on the abdomen and those fringing the lamellæ black; the hypopygium also being black. In flavus the hypopygium is yellow, its lamellæ are fringed with yellow hairs 
and the hairs of the abdomen are also yellow, except a few long ones on the hind margins of the segments; it has the third antennal joint drawn out into a long point.

\section{Gymnopternus robustus sp. nov.}

Male: Length $4 \mathrm{~mm}$. Face and front covered with grayish white pollen. Palpi black. Antennæ black, third joint slightly longer than wide somewhat conical in outline. Orbital cilia wholly black.

Thorax and abdomen blackish green, shining; pleuræ black with white pollen. Hypopygium and its lamellæ black, the latter somewhat crescent shaped with a short truncate protuberance in the middle, which makes them appear wide in the center, they are fringed with black hairs, a few of which near the middle being bent at tip.

All coxæ and femora black with black hairs and yellow tips. All tibiæ and basitarsi yellow, all tarsi being black from the tip of the first joint; posterior tibiæ with an obscure brown spot at extreme tip on posterior surface. Joints of fore tarsi as 34-15-128-10; of middle ones as 51-23-19-16-11; first two joints of posterior tarsi as 45-30. Calypters and halteres yellow, cilia of the former black.

Wings grayish, very slightly tinged with brown in front of second vein; costa slightly, but distinctly thickened at tip of first vein, tapering to. its tip; third vein bent backward a little towards its tip, parallel with fourth at tip, but slightly approaching fourth just beyond the middle of the last section of fourth vein; length of last section of fifth vein 53, of cross-vein 25 fiftieths of a millimeter.

Described from one male, taken at Manlius, N. Y., by Mr. H. H. Smith, in 1873.

Type in the Cornell University collection. 

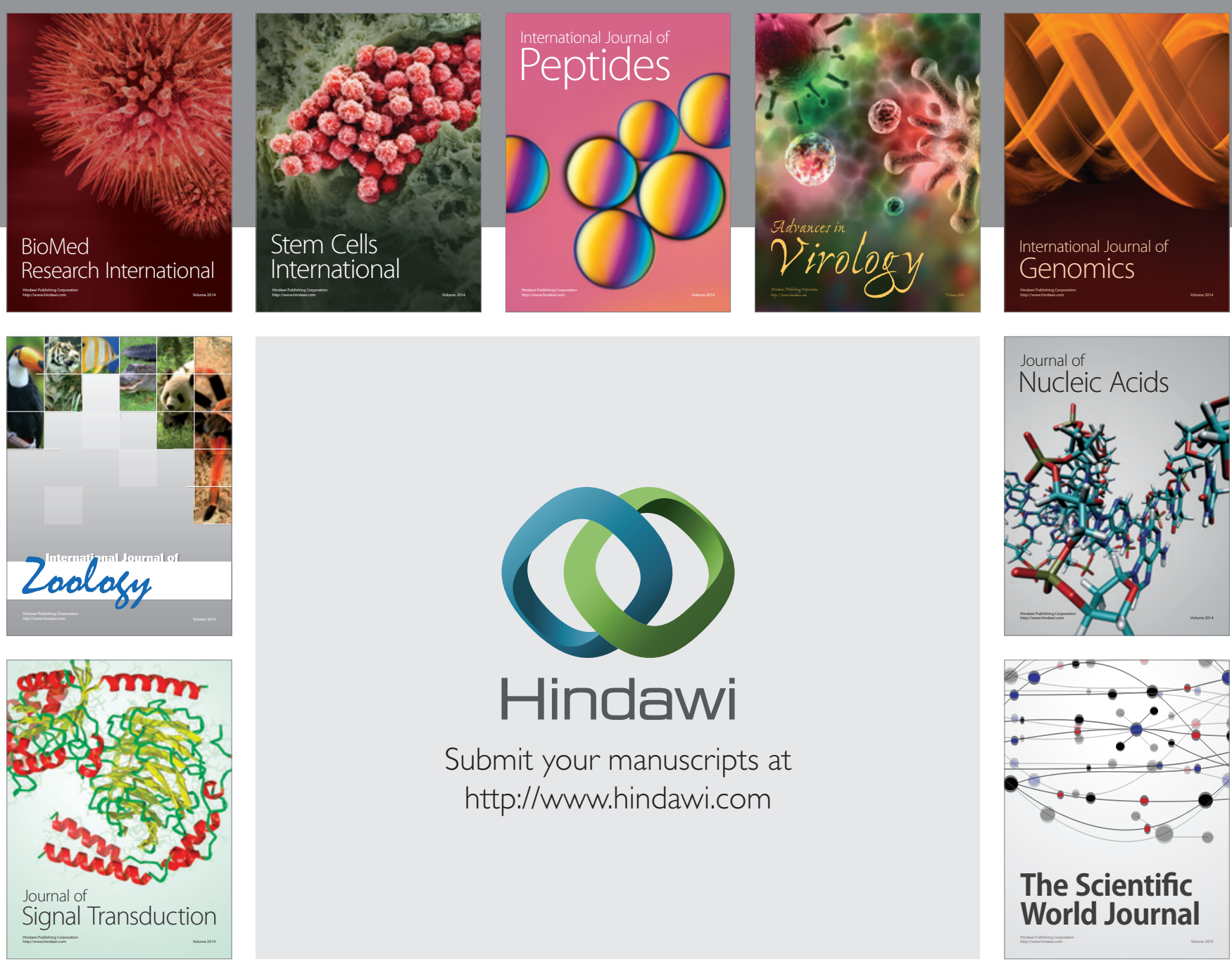

Submit your manuscripts at

http://www.hindawi.com
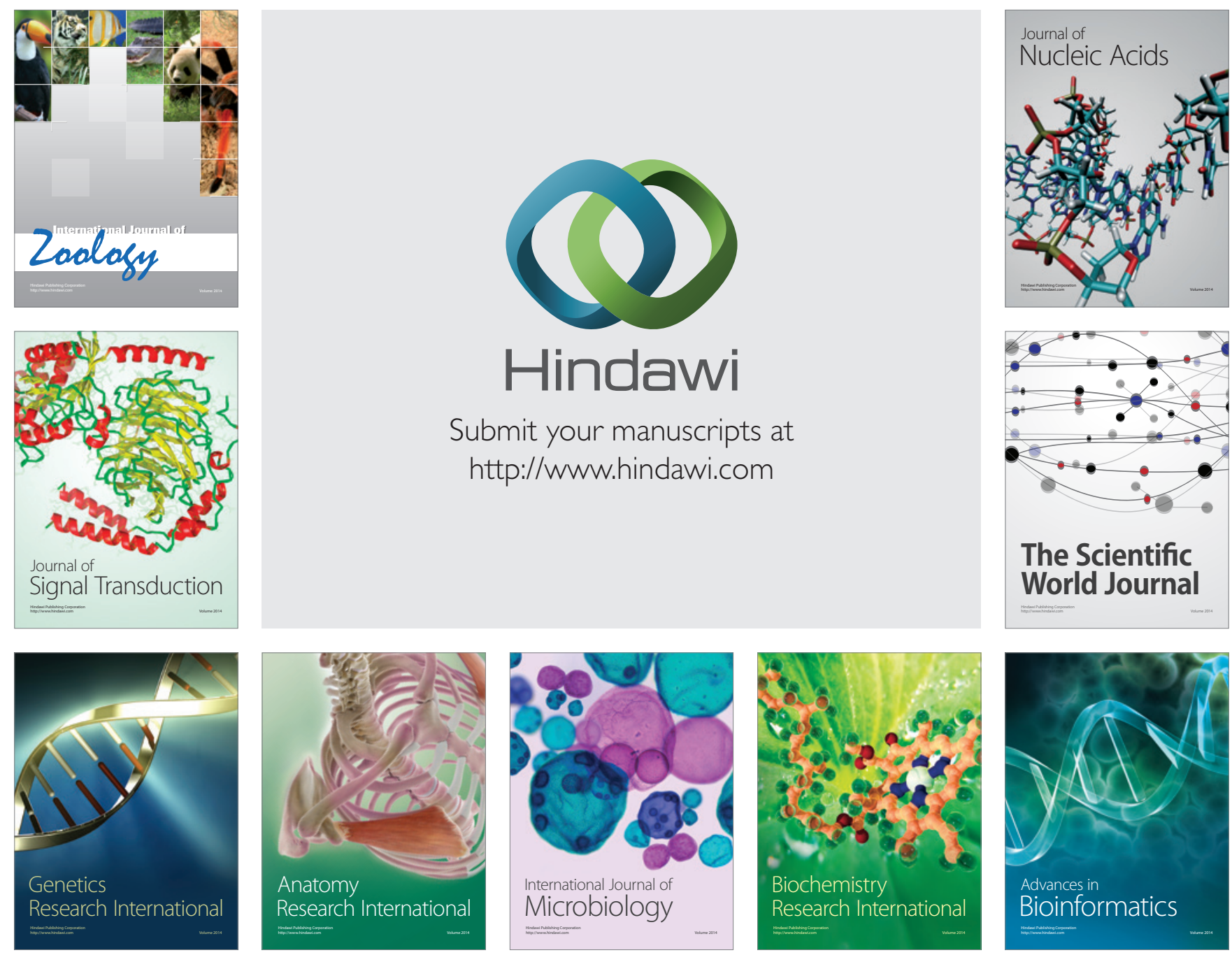

The Scientific World Journal
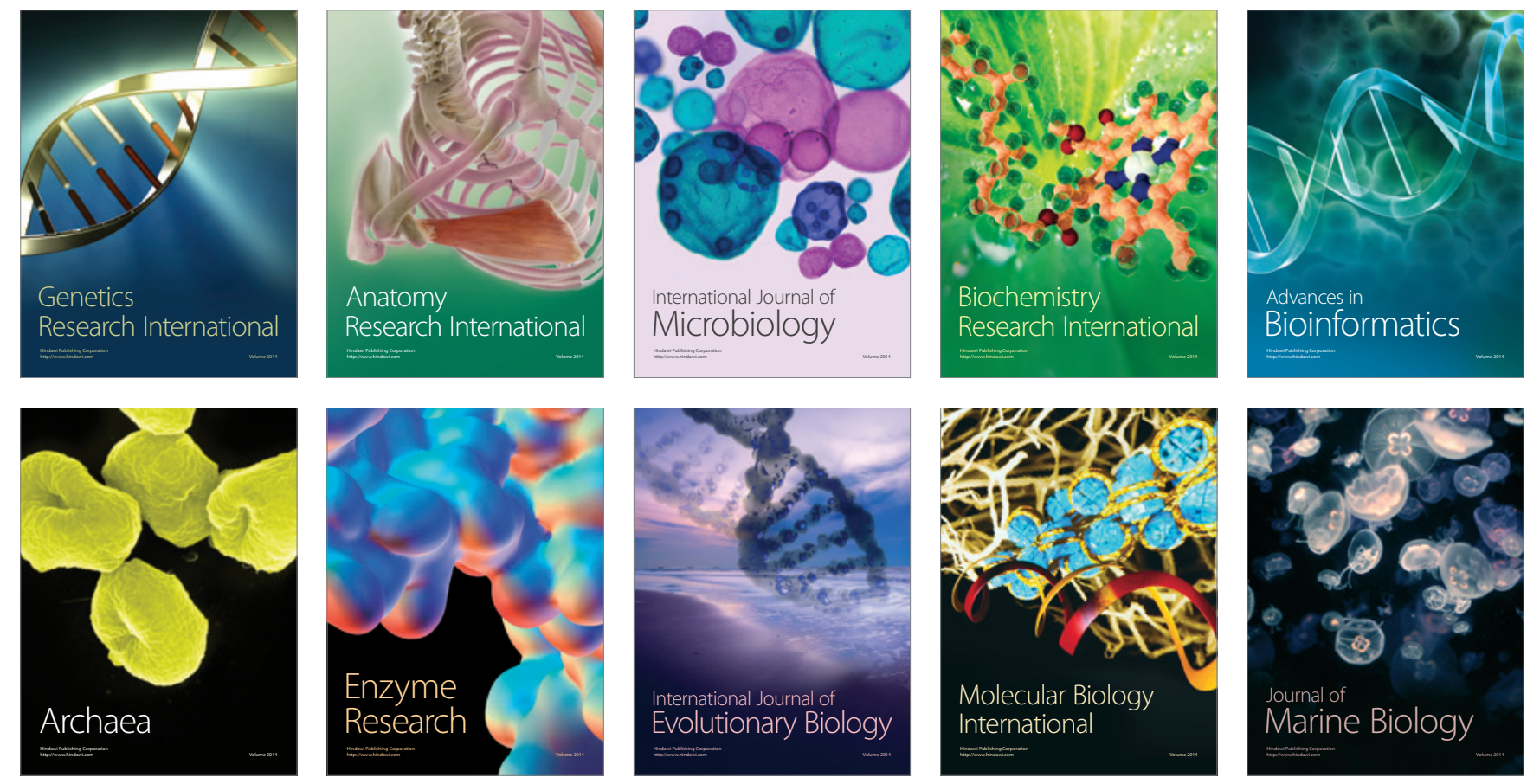